\title{
Gene flow from GM glyphosate-tolerant to conventional soybeans under field conditions in Japan
}

\author{
Yasuyuki YOSHIMURA*, Kazuhito MATSUO and Koji YASUDA \\ National Institute for Agro-Environmental Sciences, Tsukuba, Ibaraki 305-8604, Japan
}

\begin{abstract}
Natural out-crossing rates were evaluated for conventional soybeans (Glycine max (L.) Merr.) cultivated adjacent to genetically modified (GM) glyphosate-tolerant soybeans under field conditions during a four-year period in Japan. A total of 107846 progeny of 2772 plants harvested from conventional varieties were screened for glyphosate herbicide tolerance. The highest out-crossing rates, $0.19 \%$ in 2001 and $0.16 \%$ in 2002 , were observed in adjacent rows $0.7 \mathrm{~m}$ from the pollen source. The highest rate in 2004 was $0.052 \%$, which was observed at $2.1 \mathrm{~m}$. No out-crossing was observed in the rows $10.5 \mathrm{~m}$ from the pollen source over the four-year period. The farthest distances between receptor and pollen source at which out-crossing was observed were $7 \mathrm{~m}$ in 2001 , $2.8 \mathrm{~m}$ in 2002, and $3.5 \mathrm{~m}$ in 2004. The greatest airborne pollen density during the flowering period, determined

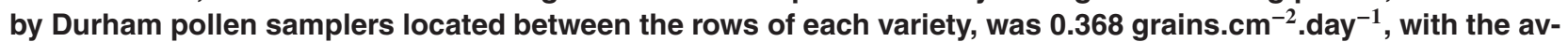
erage value at 0.18 grains. $\mathrm{cm}^{-2}$.day ${ }^{-1}$, indicating that the possibility of out-crossing by wind is minimal. Thrips species and predatory Hemiptera visited the soybean flowers more frequently during the four-year period than any other common pollinators, such as bees.
\end{abstract}

Keywords: gene flow / soybean / glyphosate-tolerant / out-crossing / pollen

Abbreviations: GM: genetically modified.

\section{INTRODUCTION}

Some GM crops have already been registered for farmers' fields in Japan, however, they have never been cultivated commercially. Soybean is one of registered crops and is an essential material in traditional Japanese food, such as tofu and miso.

GM soybeans accounted for $60 \%$ of the 90 million hectares of the soybeans planted worldwide in 2005 (James, 2006), and that area will increase steadily in the future. Introducing GM soybeans commercially to Japan could result in some farmers cultivating GM soybean next to conventional soybean fields, which could cause contamination by gene flow from the GM to the conventional varieties.

There have been several reports of natural outcrossing of conventional soybeans under field conditions in several locations in the United States. Most researchers observed that natural cross-pollination rates for soybeans grown in adjacent rows are less than $0.5 \%$ (Caviness, 1966; Chiang and Kiang, 1987; Garber and Odland, 1926; Ray et al., 2003; Woodworth, 1922). The natural out-crossing rates for closely spaced plants (less

*Corresponding author: yyoshi@ niaes.affrc.go.jp than $0.2 \mathrm{~m}$ ) have been reported to be as high as $6.32 \%$, but are usually less than 2\% (Chiang and Kiang, 1987; Cutler, 1934; Ray et al., 2003; Weber and Hanson, 1961). However, the rates between GM and conventional soybean have never been evaluated, and there have been only a few reports regarding the natural out-crossing in Asia, since most experiments were conducted in the United States. Takagi (1927) demonstrated a $0.62 \%$ natural cross-pollination rate for soybean varieties cultivated in close proximity (the distance was not given) in Korea. Kikuchi et al. (1993) observed a $0.06 \%$ rate for plants grown in adjacent rows in Japan, $0.14 \%$ for plants spaced $0.14 \mathrm{~m}$ apart, and $0.68 \%$ for plants grown on the same hill. The extent of hybridization and relationship between separation and the out-crossing rates remain uncertain in their papers. The main objective of this study was to assess the extent of hybridization and the cross-pollination rates as related to the distance from pollen sources, by cultivating GM and conventional soybeans under field conditions in Japan.

Although cross-pollination in soybeans is most likely facilitated by insects (Erickson, 1975; Erickson et al., 1978; Rust et al. 1980), the only report that investigates both the out-crossing rates and visitors to soybean flowers was conducted in the Mississippi Delta, USA (Ray 
Y. Yoshimura et al.

Table 1. Frequency of natural out-crossing rates evaluated from surviving progeny in 2001, 2002, 2003, and 2004. Conventional varieties were A3904 in 2001 and Enrei in 2002, 2003, and 2004 with AG3701RR as the pollen source.

\begin{tabular}{cccccccc}
\hline \hline Distances from pollen source $(\mathrm{m})$ & 0.7 & 1.4 & 2.1 & 2.8 & 3.5 & 7.0 & 10.5 \\
\hline 2001 Surviving progenies & 18 & 3 & 2 & 1 & 2 & 2 & 0 \\
Evaluated progenies & 9484 & 7588 & 5884 & 6039 & 5228 & 4998 & 1683 \\
Out-crossing rate (\%) & 0.19 & 0.040 & 0.034 & 0.017 & 0.038 & 0.040 & 0 \\
\hline 2002 Surviving progenies & 7 & 0 & 0 & 4 & 0 & 0 & 0 \\
Evaluated progenies & 4447 & 4370 & 4510 & 4900 & 5063 & 4481 & 5251 \\
Out-crossing rate (\%) & 0.16 & 0 & 0 & 0.08 & 0 & 0 & 0 \\
\hline 2003 Surviving progenies & 0 & 0 & 0 & 0 & 0 & 0 & 0 \\
Evaluated progenies & 497 & 694 & 629 & 705 & 698 & 788 & 970 \\
Out-crossing rate (\%) & 0 & 0 & 0 & 0 & 0 & 0 & 0 \\
\hline 2004 Surviving progenies & 1 & 0 & 2 & 1 & 1 & 0 & 0 \\
Evaluated progenies & 4169 & 3745 & 3814 & 4407 & 4526 & 4618 & 3700 \\
Out-crossing rate (\%) & 0.023 & 0 & 0.052 & 0.023 & 0.022 & 0 & 0 \\
\hline
\end{tabular}

et al., 2003). Soybeans are native to North and Central China (Hymowitz, 1970). They were introduced into Japan from China in the 7 th century and have been cultivated in Japan ever since. The long history of soybean cultivation could have led to increased insect attractiveness of soybean flowers in Japan. The second objective of this study was to study the insect visitors to soybean flowers to provide basic data on natural out-crossing under field condition in Japan.

Data for airborne soybean pollen grains have not yet been reported, since soybeans are basically selfpollinating and the flowers have the anatomical features of entomophilious plant species (Erickson and Garment, 1979). However, we investigated the airborne pollen density during the flowering period, as well as crosspollination rates and sampled the insect visitors to assess possible cross-pollination by wind.

\section{RESULTS}

The 40904 progenies of 728 A3904 plants harvested in 2001, and 33 022, 4941, and 28979 progenies of 700, 636, and 708 Enrei plants harvested in 2002, 2003, and 2004 were screened in the year following harvest by glyphosate application, since the heterozygous offspring would be glyphosate-tolerant. The numbers of surviving progenies after the applications, the numbers of the evaluated population, and the natural out-crossing rates for each row are presented in Table 1 . The highest rate in 2001 was $0.19 \%$, which was observed in the adjacent row. The rate decreased drastically beyond the second row and fluctuated between $0.017 \%$ and $0.04 \%$ from the 2 nd to 10th rows, and it reached zero at the 15 th row, which was $10.5 \mathrm{~m}$ from the pollen source. The highest rate in $2002,0.16 \%$, was observed in the adjacent row, as in 2001 , and $0.08 \%$ was observed in the fourth row, which was $2.8 \mathrm{~m}$ from the pollen source. No heterozygous offspring were found in the 4941 progenies in 2003, because we did not have enough individuals to evaluate, due to extreme drought in the field. We had only five heterozygous offspring in 2004, and the highest rate was $0.052 \%$ at $2.1 \mathrm{~m}$ from the pollen source. A single heterozygous offspring was found in the adjacent row. The farthest distance between the crossing and pollen source was $3.5 \mathrm{~m}$, for which the out-crossing rate was $0.022 \%$.

We obtained data concerning 100 to 423 insect visitors, representing five orders and sixteen species, which were collected in or near the soybean flowers during the flowering periods (Tab. 2). The thrips species, particularly Frankliniella intonsa, visited the soybean flowers more frequently every year than any other species. Predatory Hemiptera, which prey on thrips, visited them more frequently than any species other than thrips. More than 20 individuals of Coleoptera, Monolepta dichoroa, and Lepidoptera, Pieris rapae, were observed once in the four years.

The first flowering date for Enrei in 2003 was August 3 , and the flowers continued to bloom as a community for three weeks. In contrast, the date was July 28 for AG3701RR, and the flowers continued to bloom for five weeks, which included the flowering period of Enrei (Tab. 3). The first flowering dates for both varieties in 2004 were earlier than those in 2003 by about five days, and the flowering period of AG3701RR included that of Enrei, as in 2003 (data not shown). The airborne pollen densities during the flowering periods and the changes in the number of flowers observed around the pollen samplers are indicated in Figure 1 and Table 3. The highest pollen density during the flowering periods (excluding 
Gene flow from GM to conventional soybeans in Japan

Table 2. Number of insect visitors identified from sampling in square plots of $4 \mathrm{~m}^{2}$ for each variety in the morning during the flowering periods in 2001, 2002, 2003, and 2004. The number of larvae is given in parentheses.

\begin{tabular}{|c|c|c|c|c|c|}
\hline Order & Species & 2001 & 2002 & 2003 & 2004 \\
\hline \multirow{5}{*}{ Hymenoptera } & Campsomeriella annulata annulata (Fab.) & 6 & 1 & 1 & - \\
\hline & Apis mellifera (L.) & 2 & - & 1 & - \\
\hline & Helictus aerarius (Smith) & 1 & - & 1 & - \\
\hline & Megachile tsurugensis (Cockerell) & 1 & - & - & - \\
\hline & Lasiglossus occidens (Smith) & - & - & 2 & - \\
\hline \multirow[t]{4}{*}{ Thysanopreta } & Frankliniella intonsa (Trybom) & 105 & 45 & 50 & 404 \\
\hline & Thrips hawaiiensis (Morgan) & 2 & 2 & 1 & - \\
\hline & Haplothrips chinensis & - & - & 7 & 3 \\
\hline & Thrips sp. & - & - & - & 1 \\
\hline \multirow[t]{5}{*}{ Hemiptera } & Orius sauteri (Poppius) & 43 & 16 & 20 & $7(7)$ \\
\hline & Orius minutus (Linnaeus) & 1 & 6 & 12 & $2(2)$ \\
\hline & Geocoris proteus (Distant) & 10 & 6 & - & - \\
\hline & Geocoris varius & - & - & - & $3(3)$ \\
\hline & Creontiades colripes (Hsiao) & 1 & 4 & $1(1)$ & $3(2)$ \\
\hline Coleoptera & Monolepta dichoroa (Harold) & 28 & - & $4(1)$ & - \\
\hline Lepidoptera & Pieris rapae crucivara & - & 20 & - & - \\
\hline Total & & 200 & 100 & 100 & 423 \\
\hline
\end{tabular}

Table 3. First flowering date and the number of AG3701RR and Enrei flowers in 20 individuals around the Durham pollen samplers in 2003.

\begin{tabular}{|c|c|c|c|c|c|}
\hline \multirow[t]{2}{*}{ Variety } & First & \multicolumn{4}{|c|}{ Date } \\
\hline & flowering date & 6 Aug. & 11 Aug. & 18 Aug. & 22 Aug. \\
\hline$\overline{\mathrm{AG} 3701 \mathrm{RR}}$ & 28 July & 64 & 88 & 15 & 20 \\
\hline Enrei & 3 August & 123 & 55 & 9 & 4 \\
\hline
\end{tabular}

rainy days) was $0.368 . \mathrm{cm}^{-2} \cdot$ day $^{-1}$, and the average was $0.18 \cdot \mathrm{cm}^{-2} \cdot$ day $^{-1}$ (Fig. 1).

\section{DISCUSSION}

The out-crossing rates we observed for soybeans grown in adjacent rows spaced $0.7 \mathrm{~m}$ apart were less than $0.2 \%$ during the four-year period. These results are within the range obtained in several previous studies. The rates are slightly lower than those obtained by Chiang and Kiang (1987) and Ray et al. (2003), but higher than those reported by Woodworth (1922) and by Garber and Odland (1926). No individuals located in the rows $10.5 \mathrm{~m}$ from the pollen source showed out-crossing over the four-year period. The farthest distances between the plants having out-crossed and pollen source were $7 \mathrm{~m}$ in 2001, $2.8 \mathrm{~m}$ in 2002, and $3.5 \mathrm{~m}$ in 2004. Ray et al. (2003) observed a rate of $0.03 \%$ at $5.4 \mathrm{~m}$ from the pollen source. Caviness (1966) reported that the out-crossing rates observed in progenies harvested between $10.06 \mathrm{~m}$ and $15.54 \mathrm{~m}$ were $0.01 \%, 0 \%$ and $0.004 \%$ during three consecutive years. Our values were also similar to the extent of hybridization

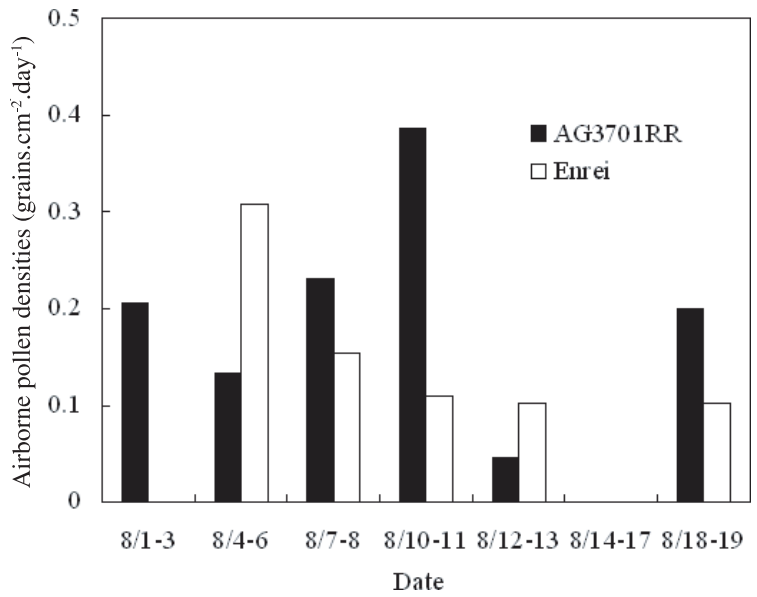

Figure 1. Airborne soybean pollen densities determined by Durham pollen samplers during the flowering period in 2003. Samplers were located between rows in the center of southern fields of AG3701RR and Enrei. The mounts were covered with Vaseline and fixed at heights of $0.4 \mathrm{~m}$ and $0.6 \mathrm{~m}$ above ground, which were $0.1 \mathrm{~m}$ lower than the plant heights of AG3701RR and Enrei. Prepared specimens of the samplers were exchanged with new ones every two to four days.

in previous experiments in which conventional soybeans were used as materials.

The rate of A3904 × AG3701RR in 2001 was higher than that of Enrei $\times$ AG3701RR in 2002, 2003, and 2004. No heterozygous offspring of Enrei $\times$ AG3701RR was detected farther than the 10th row, in which the plants were $7.0 \mathrm{~m}$ from the pollen source. We found a 


\section{Y. Yoshimura et al.}

single heterozygous offspring in the 5th row. Flowering synchronization and the existence of pollinators are critical factors for natural cross-pollination in soybeans. The flowering synchronization of A3904 and AG3701RR is expected to be longer than that of Enrei and AG3701RR, since A3904, the receptor variety used in 2001, is an indeterminate type that has a longer flowering period than Enrei, the determinate type used in 2002, 2003, and 2004.

The timing of flowering and the number of flowers in each variety are involved in determining pollen densities. Pollen was first observed in the Enrei field when the flowers around the pollen sampler began to bloom, and the amount of pollen declined as the flower numbers decreased. The greatest amount of pollen was observed in AG3701RR when the flowers bloomed abundantly. Although we cannot identify the variety of the pollen by size, color, or design, we presume that most of the pollen sampled in the Enrei field was Enrei pollen. The pollen densities, as well as the anatomical features and short life span of soybean pollen, suggest that the possibility of out-crossing by wind is minimal. Generally for wind pollination it is expected that out-crossing rates would decline exponentially with the distance from the pollen source. The rates in 2001 fluctuated between $0.19 \%$ and zero from 0.7 to $7 \mathrm{~m}$ from the pollen source, which may indicate insect pollination.

Casas (1961) noted that the frequency of natural crossing was increased by enclosing the soybean plants in cages with a population of honeybees. Ahrent and Caviness (1994) observed rates as high as $2.55 \%$ under field conditions in which beehives were present. Fujita et al. (1997) reported that the out-crossing rate for the wild soybean G. soja was $13 \%$, which is much higher than that previously reported for $G$. max. This higher out-crossing rate appears to be related to frequent visits by honeybees and carpenter bees. Rust et al. (1980) reported that soybean pollen was recovered from six wild bee species collected from soybean fields in three regions of the United States. However, soybeans are not as attractive to bees as many other plants. Nectar secretion and pollen production attract bees in the field, but those features of soybeans are generally slight (Erickson, 1975), and the number of flowers per area is less than that of any other plant in the summer.

There were fewer common pollinators, such as honeybees, over the four-year period than suspected pollinators, the Thysanoptera and Hemiptera species. Thrips, particularly Frankliniella intonsa, were observed most frequently in or near the soybean flowers. Thrips are often used as pollinators in soybean breeding in Russia (Abe et al., 2000), and were observed frequently in soybean fields in previous papers (Irwin and Yeargan, 1980; Nakayama and Yamaguchi, 2002; Ray et al., 2003). Although our data don't indicate clearly that thrips are useful pollinators, they were the most plausible suspected pollinators in our field in Tsukuba, Japan.

In this study, twenty-six heterozygous offspring, out of the total 44 heterozygous offspring obtained over four continuous years, were produced in rows adjacent to the pollen donor; this is $60 \%$ of all offspring, representing a rate of $0.14 \%$. There were two heterozygous offspring out of 14885 in the 10th row, which was $7 \mathrm{~m}$ from pollen source for four years. We could not find any heterozygous offspring in the 15 th row, which was $10.5 \mathrm{~m}$ from the pollen source. In Japan, experimental GM soybean must be cultivated $10 \mathrm{~m}$ from other soybean fields according to "Guideline for Field Test Using LMOs with Approved Type 1 Use Regulations (MAFF, 2006)", which was based on previous crossing experiments of non-GM soybeans. This study confirmed that a $10 \mathrm{~m}$ isolation distance prevented pollen flow from the GM to conventional soybean. Currently, rules area being established to regulate the co-existence of GM and non-GM crops in Japan. These result should provide useful farming information for co-existence of soybeans.

\section{MATERIALS AND METHODS}

Each year, we cultivated AG3701RR (Event 40-3-2), an indeterminate type produced in the US, as the GM glyphosate-tolerant variety. A3904, an indeterminate type, and Enrei, a determinate type produced in Japan, were cultivated in 2001 and from 2002 to 2004 as conventional varieties, respectively. The experimental field in Tsukuba, Japan, was $70 \mathrm{~m} \times 22 \mathrm{~m}$ and was divided into four equal parts; GM and conventional soybeans were cultivated in the northwest and southeast parts and the northeast and southwest parts, respectively. The soybeans were sown in June from 2001 to 2004 in 15 rows spaced $0.7 \mathrm{~m}$ apart. The in-row spacing was approximately $0.2 \mathrm{~m}$. Pesticide (parmathion) was applied a few times a year. Seed pods were harvested in November from 50 individual plants of conventional receptor varieties in the 1st, 2nd, 3rd, 4th, 5th, 10th, and 15th rows, which were located $0.7,1.4,2.1,2.8,3.5,7.0$, and $10.5 \mathrm{~m}$ from AG3701RR (the pollen source).

The harvested seeds were sown in a different experimental field the year following harvest, and the seedlings were sprayed with glyphosate $\left(2.29 \mathrm{~kg} . \mathrm{ae}^{\mathrm{h}} \mathrm{ha}^{-1}\right)$ at the three- to five-leaf stage. The surviving seedlings were counted as heterozygous offspring after two weeks. We were unable to obtain suitable growth conditions for the samples harvested in the 15th row in 2001 and in all rows in 2003.

Insects were collected by a small net or suction tube in or near the soybean flowers in four rows (length of row: $35 \mathrm{~m}$ ) in the mornings during the flowering periods in 
Gene flow from GM to conventional soybeans in Japan

2001, 2002, 2003, and 2004 for 40 minutes for each soybean. These insect visitors were taken to the laboratory, where they were identified and quantified.

The airborne pollen densities during the flowering periods were measured by Durham pollen samplers (DK1SA, Nishi Seiki, Chiba, Japan) in 2003. Samplers were located between the rows in the center of each southern field. Mounts covered thinly with Vaseline were fixed at heights of $0.4 \mathrm{~m}$ and $0.6 \mathrm{~m}$ above ground, which were $0.1 \mathrm{~m}$ lower than the plant heights of each variety. Prepared specimens of the samplers were exchanged with new ones every two to four days. The pollen was stained with Carberla solution $(5 \mathrm{~mL}$ glycerine, $10 \mathrm{~mL} \mathrm{95 \%}$ ethanol, 2 drops of saturated fuchsine, and $15 \mathrm{~mL}$ distilled water), and the pollen grains on the prepared specimens were counted using a microscope (Eclipse E600; Nikon, Tokyo).

The soybean flowers on the 20 individuals closest to the Durham pollen samplers were counted on August 6, 11,18 , and 22 in 2003.

\section{ACKNOWLEDGEMENTS}

We are grateful to Monsanto Co. for supplying the soybean (AG3701RR and A3904) seeds.

Received August 16, 2006; accepted January 6, 2007.

\section{REFERENCES}

Abe J, Kanazawa A, Shimamoto Y (2000) Wild soybean in far-east Russia: Distribution, ecology and genetic structure of populations. In Genetic diversity and in situ conservation of wild soybeans: Report of grant-in-aid for scientific research from the J.S.P.S., No. 09041135, Abe J, ed, Hokkaido University, Sapporo, pp 3-24.

Ahrent DK, Caviness CE (1994) Natural cross-pollination of twelve soybean cultivars in Arkansas. Crop Sci. 6: 211-212

Caviness CE (1966) Estimates of natural cross pollination in Jackson soybeans in Arkansas. Crop Sci. 34: 376-378

Casas E (1961) Induction of male sterility in soybeans MS thesis. North Carolina State College, Raleigh, 42 p
Chiang YC, Kiang YT (1987) Geometric position of genotypes, honeybee foraging patterns and outcrossing in soybean, Bot. Bull. Acad. Sinica 28: 1-11

Cutler GH (1934) A simple method for making soybean hybrids. J. Am. Soc. Agron. 26: 252-254

Erickson EH (1975) Variability of Floral characteristics influence honeybee visitation to soybean flowers. Crop Sci. 15: 767-771

Erickson EH, Garment MB (1979) Soya-bean flowers: nectary ultrastructure, nectar guides, and orientation on the flower by foraging honeybees. J. Apic. Res. 18: 3-11

Erickson EH, Berger GA, Shannon JG, Robbins JM (1978) Honey bee pollination increases soybean yields in the Mississippi Delta region of Arkansas and Missouri. J. Econ. Entomol. 71: 601-603

Fujita R, Ohara M, Okazaki K, Shimamoto Y (1997) The extent of natural cross-pollination in wild soybean (Glycine soja). J. Heredity 88: 124-128

Garber GJ, Odland TE (1926) Natural crossing in soybean. Am. Soc. Agron. J. 18: 967-970

Hymowitz T (1970) On the domestication of the soybean. Econ. Bot. 24: 408-421

Irwin ME, Yeargan KV (1980) Sampling phytophagous thrips on soybean. In Kogan $M$ and Herzog DC, ed, Sampling Methods in Soybean Entomology, Springer-Verlag, New York, pp 283-303

James C (2006) Preview: Global status of commercialized biotech/GM Crops: 2005, ISAAA Briefs No. 34

Kikuchi A, Murata K, Tabuchi K, Sakai S (1993) Inheritance of seed embryo color and investigation of degree of natural cross-pollination in soybeans. Breeding Sci. 43 (Suppl. 2): 112

MAFF (2006)

http://www.s.affrc.go.jp/docs/anzenka/pdf/sisin.pdf

Nakayama Y, Yamaguchi H (2002) Natural hybridization in wild soybean (Glycine max ssp. soja) by pollen flow from cultivated soybean (G. max ssp. max) in a designed population. Weed Biol. Manag. 2: 25-30

Ray JD, Kilen TC, Abel CA, Paris RL (2003) Soybean natural cross-pollination rates under field conditions. Environ. Biosafety Res. 2: 133-138

Rust RW, Mason CE, Erickson EH (1980) Wild bees on soybeans, Glycine max. Environ. Entomol. 9: 230-232

Takagi M (1927) On the frequency of the spontaneous hybridization in soybeans. Japan J. Bot. 3 (68), Abstract No. 197

Weber CR, Hanson WD (1961) Natural hybridization with and without ionizing radiation in soybeans. Crop Sci. 1: 389-392

Woodworth CM (1922) The extent of natural cross-pollination in soybeans. J. Amer. Soc. Agron. 14: 278-283 